\title{
Evaluation of the Protective Effect of Silibinin Against Diazinon Induced Hepatotoxicity and Free-Radical Damage in Rat Liver
}

\author{
Halil Beydilli ${ }^{1, *}$; Nigar Yilmaz ${ }^{2}$; Esin Sakalli Cetin ${ }^{3}$; Yasar Topal ${ }^{4}$; Ozgur Ilhan Celik ${ }^{5}$; Cem \\ Sahin ${ }^{6}$; Hatice Topal ${ }^{3}$; Ibrahim Hakki Cigerci ${ }^{7}$; Hamdi Sozen ${ }^{8}$ \\ ${ }^{1}$ Department of Emergency Medicine, School of Medicine, Mugla Sitki Kocman University, Mugla, Turkey \\ ${ }^{2}$ Department of Medical Biochemistry, School of Medicine, Mugla Sitki Kocman University, Mugla, Turkey \\ ${ }^{3}$ Department of Medical Biology, School of Medicine, Mugla Sitki Kocman University, Mugla, Turkey \\ ${ }_{5}^{4}$ Department of Pediatrics, School of Medicine, Mugla Sitki Kocman University, Mugla, Turkey \\ 5 Department of Pediatrics, School of Medicine, Mugla Sitki Kocman University, Mugla, Turkey \\ 6 Department of Medical Pathology, School of Medicine, Mugla Sitki Kocman University, Mugla, Turkey \\ ${ }_{7}^{7}$ Department of Internal Medicine, School of Medicine, Mugla Sitki Kocman University, \\ ${ }^{8}$ Department of Biology, School of Science, Afyon Kocatepe University, Afyon, Turkey \\ ${ }^{*}$ Corresponding Author: Halil Beydilli, Department of Emergency Medicine, School of Medicine, Mugla Sitki Kocman University, Mugla, Turkey. Tel: +90-2522114835, \\ E-mail: halilbeydilli@mu.edu.tr
}

Received: November 12, 2014; Revised: February 28, 2015; Accepted: March 18, 2015

\begin{abstract}
Background:Diazinon (0,0-Diethyl 0-(1-6-methyl-2-isoprophyl 4 pyrimidinyl) phosphorothioate)(DI) is a very effective organophosphate pesticide, used widely in agriculture. Consequently, data on poisoning cases secondary to DI exposure are important. The DI may affect a variety of tissues, including liver. Silibinin is a pharmacologically active constitute of Silybum marianum, with documented antioxidant activity.

Objectives: The aim of our study was to evaluate both histopathologically and biochemically whether silibinin is protective in DI induced liver damage.

Materials and Methods: Thirty two Wistar albino rats were divided into four groups, as follows: 1) control group - oral corn oil was given; 2) DI group - rats were administered orally $335 \mathrm{mg} / \mathrm{kg}$ in the corn oil solution;3) Silibinin group -100 mg/kg/day silibinin was given alone orally, every 24 hours for 7 days; 4) Silibinin + DI group - DI plus silibinin was given. All rats were sacrificed at the end of experiment. Superoxide dismutases (SOD), glutathione peroxidase (GPX), nitric oxide (NO) and myeloperoxidase(MPO) were investigated in serum and liver tissue. In addition, serum aspartate aminotransferase(AST) and alanine aminotransferase(ALT) enzyme activities were evaluated. The liver tissue was evaluated histopathologically with Hematoxilin \& Eosin dye.

Results: Biochemically, ALT,AST, NO, MPO in serum and NO,MPO in liver tissue were found to be significantly higher in DI group, compared to control group $(\mathrm{P}<0.001)$. In Group Silibinin + DI, serum AST, ALT, NO, MPO levels were significantly lower $(\mathrm{P}<0.01)$, and both serum and tissue SOD activities were significantly higher, compared to DI group $(\mathrm{P}<0.001)$. Diazinon induced histopathological changes in liver tissue were: severe sinusoidal dilatation, moderate disruption of the radial alignment of hepatocytes around the central vein, severe vacuolization in the hepatocyte cytoplasm, inflammation around central vein and portal region. In rats receiving both DI and silibinin, the DI induced changes accounted for less sinusoidal dilatation, vacuolization in the hepatocyte cytoplasm and the inflammation around central vein and portal region $(\mathrm{P}<0.05)$.

Conclusions: The DI was found to induce liver damage by oxidative stress mechanisms. Silibinin reduced the oxidative stress by inducing antioxidant mechanisms, thereby showing protective effect against DI induced liver damage. Further studies with silibinin should be performed regarding DI toxicity.
\end{abstract}

Keywords: Diazinon; Oxidative Stress; Antioxidants; Histopathology; Liver

\section{Background}

Diazinon (0,0-Diethyl 0-(1-6-methyl-2-isoprophyl 4 pyrimidinyl) phosphorothioate) (DI) has been widely used throughout the world, including Turkey, with applications in agriculture for controlling the hazardous insects and disease vectors (1). The DI is also one of the most widely known causes of toxicity on many body organs, and therefore data about its effects on humans are crucial. In addition, admission of the patients to the emergency department, with suicide attempt or accidental ingestion of DI, may be possible.
Diazinon exerts its effects on multiple tissues and cells, such as blood cells, immune system, hepatocytes, neuronal cells and renal cells, resulting in increased free radical production and depletion of tissue antioxidant mechanism (2-7). Previous studies have reported that DI may cause hepatotoxicity $(6,7)$. One of the possible mechanism of DI induced hepatotoxicity is the increasing level of reactive oxygen species (ROS) (4-7). The administrations of several antioxidants may attenuate the DI-induced hepatotoxicity.

Copyright (C) 2015, Iranian Red Crescent Medical Journal. This is an open-access article distributed under the terms of the Creative Commons Attribution-NonCommercial 4.0 International License (http://creativecommons.org/licenses/by-nc/4.0/) which permits copy and redistribute the material just in noncommercial usages, provided the original work is properly cited. 
Silibinin is a pharmacologically active constitute of Silybum marianum (8). Its antioxidant activity may have a crucial role in the effects of silibinin. It is widely used in the treatment due to its safety and lack of adverse effects (9). Recent studies have shown that silibinin protects the liver against multiple drugs and chemical induced liver injury $(10,11)$. Silibinin seems to be a promising protective agent for repairing free-radical induced damage in a variety of pathological conditions (11).

Aspartate aminotransferases (AST) and alanine aminotransferases (ALT) are intracellular aminotransferase enzymes, present in liver cells. After cell death or damage in liver cells, they are released into the circulation. Increased serum transaminases translate a susceptibility to liver damage (12).

Myeloperoxidase (MPO) is the most abundant protein in neutrophils, catalyzes the conversion of hydrogen peroxide and chloride ions into hypochlorous acid. It plays a role in down regulating the inflammatory response (13).

Superoxide dismutase (SOD) is regarded as the first line of defense against the detrimental effects of molecular oxygen radicals in cells. Superoxide is a crucial source of hydroperoxides and free radicals. The activity of SOD inhibits lipid peroxidation by catalyzing the conversion of superoxides into hydrogen peroxide and oxygen. The SOD protects the cells from superoxide toxicity via removing superoxide free radicals (14).

Endogenous nitric oxide (NO) is formed from the amino acid L-arginine with nitric oxide synthase (NOS) enzyme. Increasing the level of NO has a crucial role in the modulation of oxidative stress and tissue damage (15). It was reported that oxidative stress results in the increase of the activity of NO synthase, as a consequence to the elevation of NO release (16).

Glutathione peroxidase (GPx) is a crucial selenocysteine-containing enzyme, which catalyzes the reduction of hydroperoxides, including hydrogen peroxide, by reduced glutathione and functions to protect the cells from oxidative damage (17).

\section{Objectives}

The present investigation aimed to evaluate the antioxidant and protective efficacies of silibinin against DI induced hepatotoxicity in rats by evaluation of NO, MPO, SOD, GPx, AST, ALT and histological values.

\section{Materials and Methods}

Thirty two adult female 12 week-old Wistar albino rats (Suleyman Demirel University Experimental Research Centre, Isparta, Turkey) weighing 170 - 220 g were used for the present experiment. The animals were housed in quiet rooms $\left(20-25^{\circ} \mathrm{C} ; 50-60 \%\right.$ relative humidity) on a 12 hour light/dark cycle (7 a.m. - 7 p.m.) and allowed a commercial standard rat diet (Abalioglu Yem Sanayi, Denizli, Turkey) and water ad libitum. All animal procedures were approved by the university Ethics Committee (No:
2012/3). The experiments were performed in accordance with the Guide for the Care and use of Laboratory Animals (DHEW. Publication (NIH) 8523, 1985). Silibinin was purchased from Sigma/Aldrich Chemicals, USA.

The animals were randomly divided into four groups:

- Group 1: Control group $(\mathrm{n}=8)$; rats were given $0.3 \mathrm{~mL}$ corn oil orally;

- Group 2: DI group $(n=8)$; rats were administered a single dose of $335 \mathrm{mg} / \mathrm{kg}$ of body weight (BW) of DI (Basudin 60 EC, Syngeta Tarım San. ve Tic. AS, Izmir, Turkey) with corn oil $(1,4,7)$;

- Group 3: Silibinin group $(\mathrm{n}=8)$; silibinin was given orally, $100 \mathrm{mg} / \mathrm{kg} /$ day every 24 hours, for 7 days $(17,18)$;

- Group 4: DI + Silibinin group $(n=8)$; rats were given DI single dose of $335 \mathrm{mg} / \mathrm{kg}$ BW of DI orally and $100 \mathrm{mg} / \mathrm{kg}$ day silibinin was administered orally, every 24 hours for 7 days.

At the end of the experiment, all animals were anesthetized under intraperiteoneal injection of ketamine/xylazine ( $60 \mathrm{mg} / \mathrm{kg}$ and $6 \mathrm{mg} / \mathrm{kg}$, respectively). Blood samples were taken from intracardiac on the sterile tubes, for measuring the level of serum ALT, AST, MPO, NO, SOD and GPx. Blood samples were centrifuged and serum was separated. The blood was centrifuged at $2000 \times \mathrm{G}$ for 15 minutes, at $4^{\circ} \mathrm{C}$. The top yellow serum layer was pipetted off, without disturbing the white buffy layer. Livers were removed immediately and washed with phosphate buffer solution $(\mathrm{PBS})(\mathrm{pH}=7.4)$ and then frozen promptly in a deep freezer for biochemical analysis. All samples were protected under $-80^{\circ} \mathrm{C}$ until analysis.

\subsection{Determination of Aspartate Aminotransferase and Alanine Aminotransferase Activities}

The activities of AST and ALT were calculated spectrophotometrically in serum, using Beckman Coulter kits by autoanalyzer (Unicel D × C 800 Synchron, Brea, California, USA). The results were expressed as units per liter (U/L).

\subsection{Determination of Superoxide Dismutase Activity}

The tissue was homogenized at $16000 \mathrm{rpm}$ on ice, in 5 - $10 \mathrm{~mL}$ cold buffer, $20 \mathrm{mM}$ HEPES buffer, pH 7.2, containing 1mM EGTA, $210 \mathrm{mM}$ mannitol and $70 \mathrm{mM}$ sucrose per $\mathrm{g}$ tissue. The mixture was centrifuged at $1500 \times \mathrm{G}$ for 5 minutes, at $4^{\circ} \mathrm{C}$. The supernatant was removed. Serum should be diluted 1:5 with sample buffer. The SOD activity was measured in the supernatant and serum. The SOD was determined via Cayman's Superoxide Dismutase assay kit (Cayman Chemical Co., Ann Arbor, MI, USA) in Bio-Tek ELx-800 (Winooski, USA). The detection of superoxide radicals were generated by xanthine oxidase and hypoxanthine. One unit of SOD is defined as the amount of enzyme required to exhibit 50\% dismutation of the superoxide radical. The results were expressed as units per $\mathrm{mg}$ protein $(\mathrm{U} / \mathrm{mg}$ ) tissue, for liver tissue, and units per milliliter $(\mathrm{U} / \mathrm{mL})$ for serum. The dynamic range of the kits is $0.005-0.05 \mathrm{U} / \mathrm{mL}$ SOD. Recommended by the company 
Beydilli H et al.

for measuring formulation, the SOD was calculated by applying SOD values.

\subsection{Determination of Glutathione Peroxidase Ac- tivity}

The tissue was homogenized in 5-10 mL cold buffer (50 mM Tris-HCl, pH 7.5, 5 mM EDTA and 1 mM DTT (Dithiothreitol) per tissue. Then, it was centrifuged at $10000 \times$ $\mathrm{G}$ for 15 minutes, at $4^{\circ} \mathrm{C}$. The supernatant was removed after centrifugation. The blood was centrifuged at 700 $1000 \times \mathrm{G}$ for 10 minutes, at $4^{\circ} \mathrm{C}$. The serum was removed. The GPx activity was measured in liver tissue and serum samples. The GPx activity was determined via Cayman's GPx assay kit (Cayman Chemical Co., Ann Arbor, MI, USA) in Bio-Tek ELx-800. The GPx activity was measured indirectly by a coupled reaction with glutathione reductase. The oxidized glutathione was produced upon reduction of hydroperoxide by GPx. The results were expressed as units per mg protein $(\mathrm{U} / \mathrm{mg})$ tissue, for liver tissue, and units per milliliter $(\mathrm{U} / \mathrm{mL})$, for serum. The dynamic range of the assay is only limited by the accuracy of the absorbance measurement.

\subsection{Determination of Nitric Oxide Level}

The tissue was homogenized in PBS ( $\mathrm{pH} 7.4$ ) and centrifuged at $10000 \times \mathrm{G}$ for 20 minutes to create the supernatant. Total NO assay was performed by spectrophotometry at $540 \mathrm{~nm}$ using nitrate/nitrite colorimetric assay kit (Cayman, Ann Arbor, Michigan USA) in Bio-Tek ELx-800. The assay was based on nitrate and nitrite determinations. The nitrate and nitrite are the stable end products of the reaction of NO with molecular oxygen. The total accumulation of nitrate and nitrite in serum and liver tissue was measured. The results were expressed as $\mu \mathrm{m} / \mathrm{g}$ protein.

\subsection{Determination of MPO Activity}

The quantitative detection of MPO was used by an enzyme-linked immunosorbent assay (ELISA) kit (MPO Instant Elisa, eBioscience, Vienna, Austria) in Bio-Tek ELX800 . The results were expressed as $\mathrm{ng} / \mathrm{mL}$ protein.

\subsection{Histopathology of Liver Tissue}

The liver tissue was also removed for histopathological investigation. The specimens were fixed in $10 \%$ formalin subsequent overnight and then were dehydrated by immersion in a series of alcohol solutions of various concentrations, cleared in xylene and paraffin embedded tissue sections. The tissue samples were then infiltrated with paraffin as blocks, sectioned ( $5 \mu \mathrm{m}$-thick slides). The prepared samples were examined under a light microscope according to the severity of the lesions modified from Yehia et al. (19). Each parameter was scored between 0 and 3 (0: normal, 1: mild, 2: moderate and 3: severe) and according to the point total, lesions were classified into three grades (grade 1: 1-5 points, grade 2: 6 - 10 points and grade 3:11-15 points) $(12,13)$.

Six parameters of liver damage were evaluated:

1. Sinusoidal dilatation;

2. Distortion radial alignment around central vein;

3. Vacuolization in hepatocytes;

4. Inflammation in the portal area and around central vein;

5. Hepatocellular necrosis;

6. Eosinophils infiltration of in the periportal field or around central vein.

\subsection{Statistical Analysis}

Data were analyzed using a commercially available statistics software package (SPSS Statistics for Windows, Version 20.0. IBM Corp., Armonk, NY, USA). All data were presented as the mean \pm SD for comparisons. Comparisons between groups were performed using the KruskalWallis analysis of variance for unpaired comparisons, followed by the Mann Whitney U test. The $\mathrm{P}<0.05$ was considered significant.

\section{Results}

\subsection{Biochemical Results}

The levels of NO and MPO in serum and liver tissue were found to be significantly increased in the DI group, compared to control group $(\mathrm{P}<0.0001)$ (Tables 1 and 2$)$. The activity of ALT and AST were found to be significantly increased in DI group, compared to control group (P $<0.001$ ) (Table 1). The levels of NO and MPO in serum were found to be significantly decreased in DI + silibinin group, compared with DI group $(\mathrm{P}<0.01$ and $\mathrm{P}<0.001)$. When comparing DI + silibinin group to DI group the activities of AST and ALT were found decreased (Tables 1 and 2).

There was no significant statistical difference between the tissue or serum GPx activities, for all groups. The serum and tissue SOD activity was found increased in DI + silibinin group, when compared to DI group $(\mathrm{P}<0.001)$ (Table 1).

\subsection{Histopathological Results}

Hepatocytes of control group (Figure 1 A) and silibinin group (Figure $1 \mathrm{~B}$ ) were observed to have a normal structure (Figure 1). It was determined histopathologically that the liver tissue intoxicated by DI was significantly damaged (Grade 3).

In histopathological examination, rats administered DI showed severe sinusoidal dilatation, moderate disrupt radial alignment of hepatocytes, severe vacuolization of hepatocyte cytoplasm, and centrilobular necrosis ( $\mathrm{P}<$ 0.05 ) (Figure 2). In contrast, rats in DI + Silibinin group exhibited these changes significantly, especially inflammation around the central vein and portal space $(\mathrm{P}<$ 0.05) (Figure 3). 


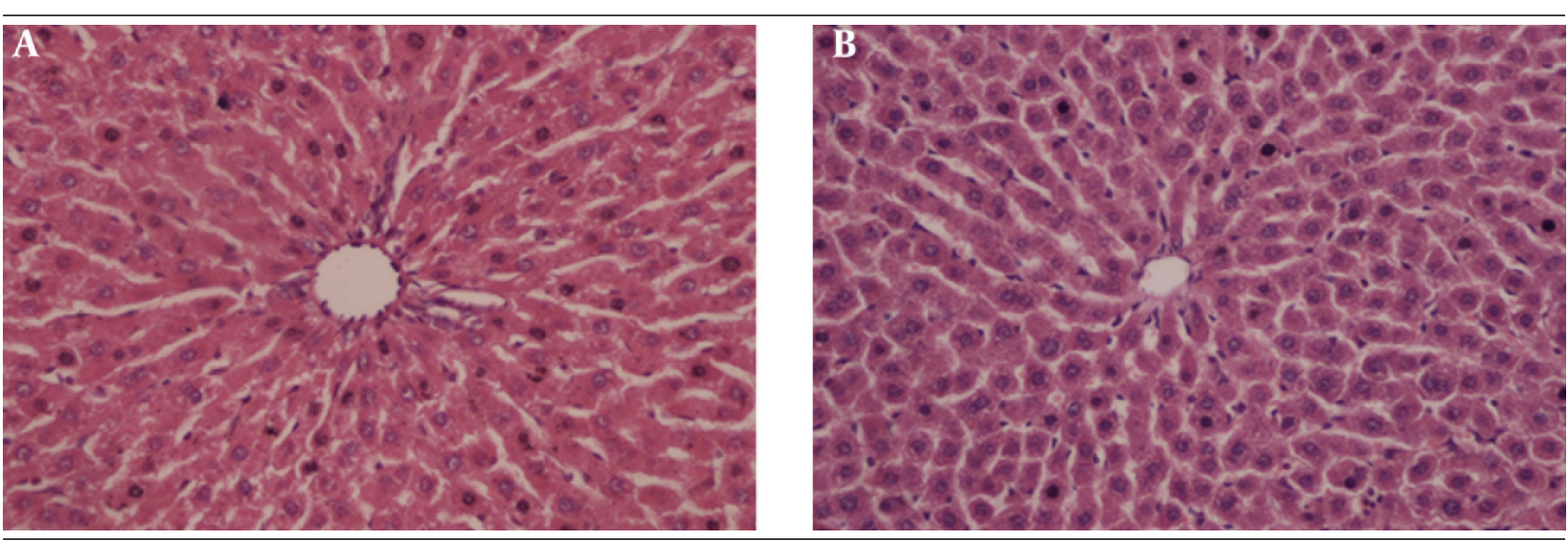

Figure 1. A, Control Group (H \& E × 40); B, Silibinin Group (H \& E × 40), Normal Liver Morphology
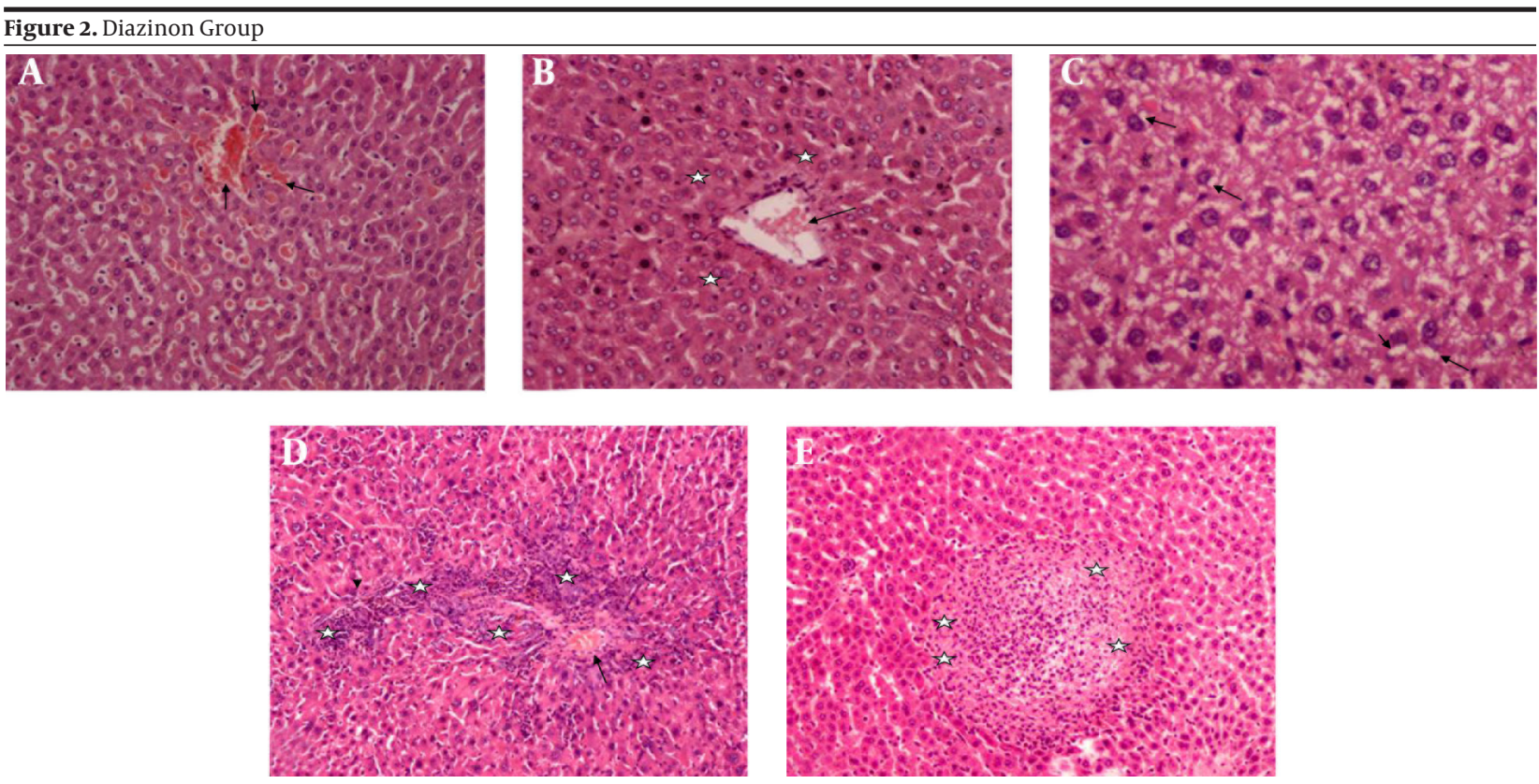

A, Dilatation in sinusoids (arrows) (H \& E $\times 40)$; B, Cellular disruption (stars) around central vein (arrow) $(\mathrm{H} \& \mathrm{E} \times 40)$; C, Vacuolation (arrows) (H \& E $\times 200)$ D, Mononuclear inflammatory cells (stars) among hepatic cells, around the central vein (arrow) and portal space (arrow head) (H \& E $\times 40)$; E, Hepatocellular necrosis (stars) $(\mathrm{H} \& \mathrm{E} \times 40)$.

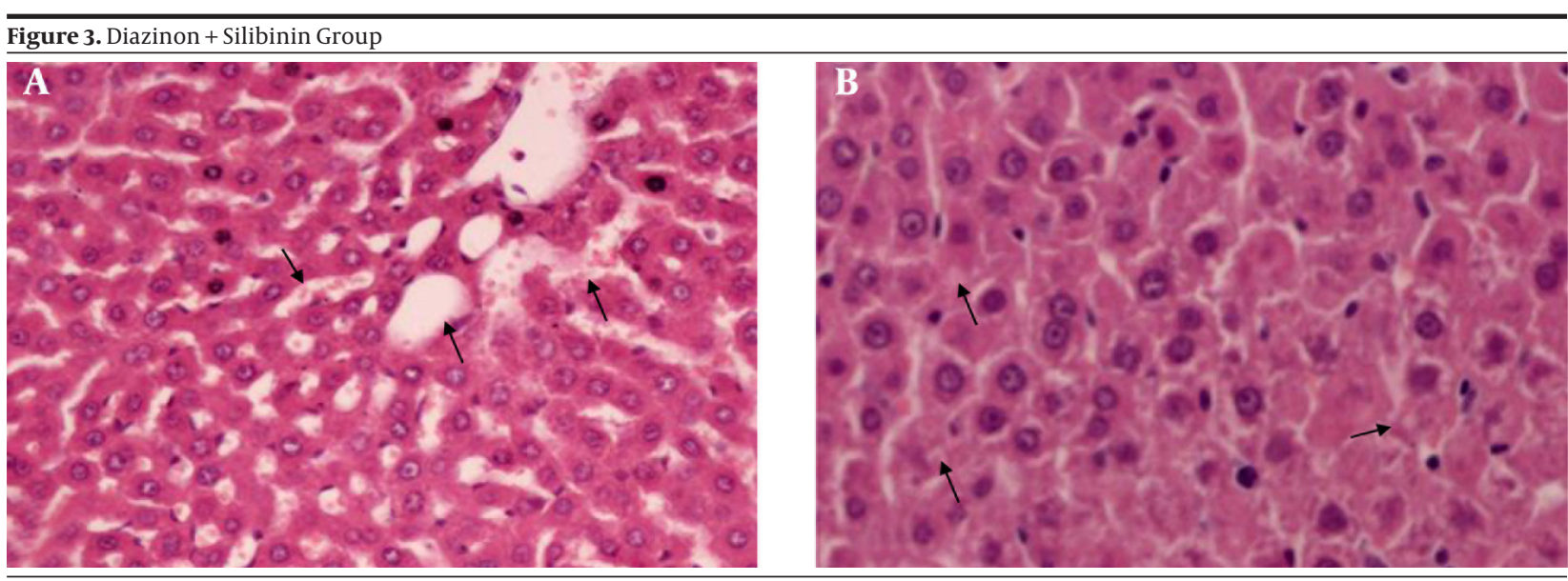

A, Mild dilatation in sinusoid (arrows) (H \& E × 100); B, Minimal vacuolation (arrows) (H \& E × 200); C: Mild inflammation (stars) around the central vein (arrow) and portal space (arrow head) $(\mathrm{H} \& \mathrm{E} \times 100)$. 
Beydilli Het al.

Table 1. Biochemical Serum Values of Four Groups of Rats ${ }^{a}$, b

\begin{tabular}{|c|c|c|c|c|c|c|}
\hline Groups & AST, U/L & ALT, U/L & SOD, U/mL & GPx, U/mL & $\mathbf{N O}, \mu \mathrm{m} / \mathrm{g}$ & MPO, ng/mL \\
\hline Control group & $107.63 \pm 22.37$ & $55.13 \pm 13.04$ & $0.1 \pm 0.02$ & $3.48 \pm 0.98$ & $1.43 \pm 0.73$ & $1.51 \pm 1.02$ \\
\hline DI group & $80.00 \pm 13.9$ & $90.00 \pm 10.18$ & $0.09 \pm 0.02$ & $3.74 \pm 2.77$ & $7.13 \pm 2.73$ & $4.83 \pm 1.60$ \\
\hline Silibinin group & $90.5 \pm 11.25$ & $44.88 \pm 3.22$ & $3.69 \pm 2.58$ & $7.95 \pm 2.68$ & $1.26 \pm 0.72$ & $1.19 \pm 0.53$ \\
\hline DI + Silibinin group & $105 \pm 23.34$ & $54.25 \pm 9.99$ & $0.52 \pm 0.34^{c}$ & $7.481 \pm 2.43$ & $2.54 \pm 1.35^{d}$ & $0.81 \pm 0.33^{e}$ \\
\hline
\end{tabular}

a Abbreviations: ALT, Alanine aminotransferase; AST, Aspartate aminotransferase; GPx, Glutathione peroxidase; MPO, Myeloperoxidase; NO, Nitric oxide; SOD, Superoxide dismutases.

$\mathrm{b}$ Data are presented as Mean $\pm \mathrm{SD}$ for $\mathrm{n}=8$.

c $\mathrm{P}<0.05$ SOD, DI + silibinin compared with DI group.

d $\mathrm{P}<0.05 \mathrm{NO}, \mathrm{DI}+$ silibinin compared with DI group.

e $\mathrm{P}<0.05 \mathrm{MPO}, \mathrm{DI}+$ silibinin compared with DI group.

Table 2. GPx, SOD, NO and MPO Liver Tissue Values of Four Groups of Rats ${ }^{\text {a, }} \mathrm{b}$

\begin{tabular}{lcccc}
\hline Groups & GPx, U/mg & SOD, $\mathbf{U} / \mathbf{m g}$ & NO, $\mu \mathbf{m} / \mathbf{g}$ & MPO, ng/mL \\
\hline Control group & $0.89 \pm 0.21$ & $1.6 \pm 0.47$ & $2.86 \pm 1.84$ & $3.51 \pm 2.40$ \\
DI group & $0.76 \pm 0.23$ & $2.70 \pm 1.71$ & $9.45 \pm 2.71$ & $7.54 \pm 3.32$ \\
Silibinin group & $0.96 \pm 0.29$ & $3.84 \pm 1.48$ & $2.2 \pm 0.01$ & $4.56 \pm 2.26$ \\
DI + Silibinin group & $0.18 \pm 0.11$ & $2.82 \pm 0.83$ & $5.9 \pm 1.14^{\mathrm{C}}$ & $3.73 \pm 1.1 \mathrm{~d}^{\mathrm{d}}$ \\
\hline
\end{tabular}

a Abbreviations: GPX, Glutathione peroxidase; MPO, Myeloperoxidase; NO, Nitric oxide; SOD, Superoxide dismutases.

$\mathrm{b}$ Data are presented as Mean \pm SD for $\mathrm{n}=8$.

c $\mathrm{P}<0.05 \mathrm{NO}, \mathrm{DI}+$ Silibinin, compared with DI group.

$\mathrm{d} \mathrm{P}<0.05 \mathrm{MPO}, \mathrm{DI}+$ Silibinin, compared with DI group

\section{Discussion}

The levels of ALT, AST, NO and MPO in serum were found increased in DI group, when compared with control group. We suggest that DI induced a significant liver damage. Silibinin reduced the levels of AST, ALT, NO, MPO in silibinin + DI group, compared with DI group. Silibinin, given to rats with DI, showed a significant protective activity against liver damage induced by DI. In addition, the level of SOD in serum and liver tissue increased via silibinin in silibinin+DI group (Table 2). In histopathological examination, DI caused severe sinusoidal dilatation and severe vacuolation, inflammation around the portal area and central vein and disrupted the radial alignment around the central vein in hepatocytes. Silibinin significantly reversed the DI-induced sinusoidal dilatation, severe vacuolization and inflammation around the central vein in hepatocytes $(\mathrm{P}<0.05)(19,20)$.

The liver is a very crucial organ for the detoxification processes and oxidative stress is thought to be a key mechanism of hepatocellular injury. The liver tissue was the major site of DI metabolism, by assembling a great quantity of its metabolites (21). In the present study, we suggest that DI increased the reactive oxygen species (ROS) in liver tissue and silibinin carries out free-radicaleliminating activity and extensive antioxidant effect. Similarly, in previous studies, it was been shown that DI caused increases in lipid peroxidation $(4,22)$. It was reported that DI exposure has been implicated in inducing oxidative stress increased nitrate and nitrite. The MPO, which is a peroxidase enzyme that synthetizes hypochlorous acid from $\mathrm{H}_{2} \mathrm{O}_{2}$ and chloride, plays an important role, as a powerful oxidant, which utilizes free radicals (13, 23-25). In this study, DI exposure could induce oxidative stress by the increased NO, MPO concentrations, which should induce membrane lipid peroxidation, resulting in liver injury. These results were correlated with previous reports of Messarah et al. who showed DI might generate ROS (26). It was reported that silibinin has antioxidant effects (27). To the best our knowledge, the current study is the first to investigate the silibinin antioxidant effects on DI induced hepatotoxicity. Oxidative stress induced by DI administration is also demonstrated by a highly significant increase in the activities NO and MPO and our results are in agreement with previous reports $(26,27)$. The DI affects the mitochondrial membrane transportation in rat liver (18). Diazinon binds extensively to biological membranes, especially to the phospholipids bilayers (28). Silibinin acts on the polar head group of phospholipids of the cellular membrane. It was reported that silibinin act as an excellent protective agent against lipid peroxidation on cellular membrane (29). Previous studies have reported the protective role of silibinin via scavenging free radicals and antioxidant properties (10). Silibinin is membranotropic in nature and it has been found to bind firmly to the hepatocellular membrane. 
Silibinin has a role in metabolic and cell-regulating actions via antioxidative mechanism, which is regarded as a major hepatoprotective effect.

In addition, ALT and AST enzymes activities represent a marker of hepatic function when determining hepatotoxicity. The DI exposure resulted in the increase of the activities of serum AST and ALT. The phenomenon may occur due to disturbing the transport function of the hepatocytes. In a previous study, silibinin repair function in hepatotoxicity was reported thorough the reduction in the serum levels of ALT and AST enzymes (30). Probably, increases of serum ALT and AST enzymes activities are one of the important markers for the diagnosis of liver damage. In addition, by increasing MPO, NO levels, DI plays role in pathogenesis of hepatic toxicity via oxidative stress mechanism. The MPO, which is the most abundant protein in neutrophils and catalyzes the conversion of hydrogen peroxide and chloride ions into hypochlorous acid, plays a role in down-regulating the inflammatory response (13). However, in non-infectious diseases, MPO that was found increased was associated with strong oxidative activity. The activity of MPO in the oxidation of DI was reported previously (31). Silibinin counteracted the inflammatory process by decreasing the MPO pathway and also by preventing free radical production. Liver injury, marked as centrilobular necrosis and neutrophilic infiltration around centrilobular area, could be seen in $\mathrm{H}$ \& E stained rat liver cells. In this study, the activity of MPO and histopathological results are correlated about hepatotoxicity.

Silibinin has been intensively studied in vitro, in vivo and also, in clinical trials. Van Wenum et al. reported that silibinin used in the treatment of cirrhosis, hepatitis and alcohol-induced liver disease, is usually connected with antioxidant action (32). Silibinin is extensively applied due to its safety and lack of adverse effects. We found an increased activity of plasma antioxidant enzymes, namely SOD in DI + silibinin group. The SOD is assumed to be the most effective antioxidant (33). Therefore, it is regarded as the first line of defense against the detrimental effects of molecular oxygen radicals in cells. Superoxide is a crucial source of hydroperoxides and free radicals. The activity of SOD inhibits lipid peroxidation by catalyzing the conversion of superoxides into hydrogen peroxide and oxygen (14). The SOD protects the cells from superoxide toxicity via removing superoxide free radicals. Silibinin also restored SOD activity. The increased hepatic SOD activity we observed in the group treated with silibinin. Accordingly, the co-administration of silibinin, after DI exposure, increased SOD levels and ameliorated the oxidative system. The co-administration of silibinin reduced the detrimental effects of DI by possibly scavenging or neutralizing ROS. These results showed that silibinin might have a beneficial role in lowering DI toxicity. Furthermore, a protective effect of silibinin has also been reported against $\mathrm{N}$-nitrosodimethylamine induced oxidative stress. Silibinin caused increases of SOD in liver tissue against $\mathrm{N}$-nitrosodimethylamine (34).
Lipid peroxidation starts as a consequence of ROSinduced isolation of hydrogen from polyunsaturated fatty acids (PUFAs) from the cellular membrane, which results in the formation of relatively stable compounds, like NO. Increasing the level of NO has a crucial role in the modulation of oxidative stress and tissue damage (15). It was reported that oxidative stress results in increasing the activity of NO synthase, as a consequence of the elevation of NO release (16). The DI induced the secretion of excess NO reaction with the superoxide anion to generate the peroxynitrite radical involved in the toxification process. Silibinin treatment significantly reduced lipid peroxidation, as an antioxidant. Therefore, silibinin treatment repaired the excess NO reaction. Treatment with silibinin effectively decreased the levels of NO. It has been reported that silibinin scavenges nitrogen species. Similarly, Prabu et al. found that the level of NO decreased as a result of silibinin treatment against arsenic induced toxicity (11).

The GPx is a crucial selenocysteine-containing enzyme, which catalyzes the reduction of hydroperoxides, including hydrogen peroxide, by reduced glutathione and functions to protect the cell from oxidative damage (17). It was reported that DI induced oxidative toxicity through oxidation of GPx (35). In another study, the GPx activity values were found to be non-significantly different between the DI group and DI + N-acetyl cysteine group. Similarly, in our study, GPx activity was not found significantly different between DI group and DI + silibinin group.

In conclusion, our present results demonstrate that silibinin exerts hepatoprotective, antioxidant, free radical scavenging effects against DI induced hepatotoxicity. It may be suggested that silibinin is convenient as a therapeutic agent for the amelioration of DI induced hepatotoxicity. However, further studies are required in order to understand and quantify the beneficial effects of silibinin in DI induced hepatotoxicity and its possible clinical use.

\section{Acknowledgements}

The authors thank the heads and staffs of the Suleyman Demirel University Experimental Research Center, Isparta, Turkey and Mugla Sitki Kocman University Scientific Research Projects, Mugla, Turkey. Also, our thanks go to the Coordination Unit for their financial and technical supports.

\section{Authors' Contributions}

Study concept and design: Halil Beydilli, Nigar Yilmaz; animal procedures and sampling: Halil Beydilli, Esin Sakalli Cetin, Hamdi Sozen; analysis and interpretation of data:Yasar Topal, Hatice Topal; drafting of the manuscript: Halil Beydilli, Cem Sahin; critical revision of the manuscript for important intellectual content: Nigar Yilmaz, Halil Beydilli; statistical analysis: Cem Sahin; study supervision: Halil Beydilli, Ibrahim Hakki Cigerci; histopathologic evaluation: Ozgur Ilhan Celik. 


\section{Funding/Support}

The research received funding from the Mugla Sitki Kocman University Scientific Research Projects Coordination Unit, Mugla, Turkey.

\section{References}

1. Shah MD, Iqbal M. Diazinon-induced oxidative stress and renal dysfunction in rats. Food Chem Toxicol.2010;48(12):3345-53.

2. Galloway T, Handy R. Immunotoxicity of organophosphorous pesticides. Ecotoxicology. 2003;12(1-4):345-63.

3. Zarichi Baghlani K, Saberi M, Rasooli Vani J. Protective effects of guanosine on Diazinon induced oxidative stress in neuralgia U373MG cell line. Trauma Mon. 2011;16(3):157-61.

4. Yilmaz N, Yilmaz M, Altuntas I. Diazinon-induced brain toxicity and protection by vitamins E plus C. Toxicol Ind Health. 2012;28(1):51-7.

5. Giordano G, Afsharinejad Z, Guizzetti M, Vitalone A, Kavanagh TJ, Costa LG. Organophosphorus insecticides chlorpyrifos and diazinon and oxidative stress in neuronal cells in a genetic model of glutathione deficiency. Toxicol Appl Pharmacol. 2007;219(2-3):181-9.

6. Shadnia S, Dasgar M, Taghikhani S, Mohammadirad A, Khorasani R, Abdollahi M. Protective Effects of alpha-Tocopherol and N-Acetyl-Cysteine on Diazinon-Induced Oxidative Stress and Acetylcholinesterase Inhibition in Rats. Toxicol Mech Methods. 2007;17(2):109-15.

7. Teimouri F, Amirkabirian N, Esmaily H, Mohammadirad A, Aliahmadi A, Abdollahi M. Alteration of hepatic cells glucose metabolism as a non-cholinergic detoxication mechanism in counteracting diazinon-induced oxidative stress. Hum Exp Toxicol. 2006;25(12):697-703.

8. Trappoliere M, Caligiuri A, Schmid M, Bertolani C, Failli P, Vizzutti F, et al. Silybin, a component of sylimarin, exerts anti-inflammatory and anti-fibrogenic effects on human hepatic stellate cells.J Hepatol. 2009;50(6):1102-11.

9. Trouillas P, Marsal P, Svobodova A, Vostalova J, Gazak R, Hrbac J, et al. Mechanism of the antioxidant action of silybin and 2,3-dehydrosilybin flavonolignans: a joint experimental and theoretical study.J Phys Chem A. 2008;112(5):1054-63.

10. Gazak R, Walterova D, Kren V. Silybin and silymarin--new and emerging applications in medicine. Curr Med Chem. 2007; 14(3):315-38.

11. Prabu SM, Muthumani M. Silibinin ameliorates arsenic induced nephrotoxicity by abrogation of oxidative stress, inflammation and apoptosis in rats. Mol Biol Rep. 2012;39(12):11201-16.

12. Andreoli TE, Carpenter CCJ, Cecil RLF. Cecil Essentials of Medicine 3rd edMichigan: Saunders; 1995.

13. Klebanoff SJ. Myeloperoxidase. Proc Assoc Am Physicians. 1999; 111(5):383-9.

14. Beyer W, Imlay J, Fridovich I. Superoxide dismutases. Prog Nucleic Acid Res Mol Biol.1991;40:221-53.

15. Tutanc M, Arica V, Yilmaz N, Nacar A, Zararsiz I, Basarslan F, et al. Effects of erdosteine on cyclosporin-A-induced nephrotoxicity. Hum Exp Toxicol. 2012;31(6):565-73.

16. Peresleni T, Noiri E, Bahou WF, Goligorsky MS. Antisense oligodeoxynucleotides to inducible NO synthase rescue epithelial cells from oxidative stress injury. Am J Physiol.1996;270(6 Pt 2):F971-7.
17. Arthur JR. The glutathione peroxidases. Cell Mol Life Sci. 2000;57(13-14):1825-35.

18. Nakagawa Y, Moore G. Role of mitochondrial membrane permeability transition in p-hydroxybenzoate ester-induced cytotoxicity in rat hepatocytes. Biochem Pharmacol.1999;58(5):811-6.

19. Yehia MA, El-Banna SG, Okab AB. Diazinon toxicity affects histophysiological and biochemical parameters in rabbits. Exp Toxicol Pathol. 2007;59(3-4):215-25.

20. Alp H, Aytekin I, Esen H, Basarali K, Kul S. Effects of caffeic acid phenethyl ester, ellagic acid, sulforaphane and curcumin on diazinon induced damage to the lungs, liver and kidneys in an acute toxicity rat model. Kafkas Univ Vet Fak Derg. 2011; 17(6):927-33.

21. Giray B, Gurbay A, Hincal F. Cypermethrin-induced oxidative stress in rat brain and liver is prevented by vitamin $\mathrm{E}$ or allopurinol. Toxicol Lett. 2001;118(3):139-46.

22. Akturk O, Demirin H, Sutcu R, Yilmaz N, Koylu H, Altuntas I. The effects of diazinon on lipid peroxidation and antioxidant enzymes in rat heart and ameliorating role of vitamin $\mathrm{E}$ and vitamin C. Cell Biol Toxicol. 2006;22(6):455-61.

23. Mehta A, Verma RS, Srivastava N. Chlorpyrifos induced alterations in the levels of hydrogen peroxide, nitrate and nitrite in rat brain and liver. Pesticide Biochem Physiol. 2009;94(2-3):55-9.

24. Klebanoff SJ. Myeloperoxidase: friend and foe. J Leukoc Biol. 2005;77(5):598-625.

25. Heinecke JW, Li W, Francis GA, Goldstein JA. Tyrosyl radical generated by myeloperoxidase catalyzes the oxidative cross-linking of proteins. J Clin Invest. 1993;91(6):2866-72.

26. Messarah M, Amamra W, Boumendjel A, Barkat L, Bouasla I, Abdennour $\mathrm{C}$, et al. Ameliorating effects of curcumin and vitamin $\mathrm{E}$ on diazinon-induced oxidative damage in rat liver and erythrocytes. Toxicol Ind Health. 2013;29(1):77-88.

27. Sozmen M, Devrim AK, Tunca R, Bayezit M, Dag S, Essiz D. Protective effects of silymarin on fumonisin $\mathrm{B}(1)$-induced hepatotoxicity in mice. J Vet Sci. 2014;15(1):51-60.

28. Lee AG, Malcolm East J, Balgavy P. Interactions of insecticides with biological membranes. Pesticide Sci.1991;32(3):317-27.

29. Erlejman AG, Verstraeten SV, Fraga CG, Oteiza PI. The interaction of flavonoids with membranes: potential determinant of flavonoid antioxidant effects. Free Radic Res. 2004;38(12):1311-20.

30. Cacciapuoti F, Scognamiglio A, Palumbo R, Forte R, Cacciapuoti F. Silymarin in non alcoholic fatty liver disease. World J Hepatol. 2013;5(3):109-13.

31. Lazarević-Pašti T, Čolović M, Savić J, Momić T, Vasić V. Oxidation of diazinon and malathion by myeloperoxidase. Pesticide Biochem Physiol. 2011;100(2):140-4.

32. van Wenum E, Jurczakowski R, Litwinienko G. Media effects on the mechanism of antioxidant action of silybin and 2,3-dehydrosilybin: role of the enol group. J Org Chem. 2013;78(18):9102-12.

33. Sirmali M, Solak O, Tezel C, Sirmali R, Ginis Z, Atik D, et al. Comparative analysis of the protective effects of caffeic acid phenethyl ester (CAPE) on pulmonary contusion lung oxidative stress and serum copper and zinc levels in experimental rat model. Biol Trace Elem Res. 2013;151(1):50-8.

34. Ezhilarasan D, Karthikeyan S, Vivekanandan P. Ameliorative effect of silibinin against N-nitrosodimethylamine-induced hepatic fibrosis in rats. Environ Toxicol Pharmacol. 2012; 34(3):1004-13.

35. Shadnia S, Ashrafivand S, Mostafalou S, Abdollahi M. N-acetylcysteine a Novel Treatment for Acute Human Organophosphate Poisoning. Int J Pharmacology. 2011;7(6). 